\title{
Mercury haloes in air above ore deposits and faults on Vancouver Island, BC, Canada
}

\author{
ALEXEI S. RUKHLOV ${ }^{1}$, LUKE OOTES ${ }^{1}$, ADRIAN S. \\ HICKIN $^{1}$ AND NIKOLAY R. MASHYANOV ${ }^{2}$ \\ ${ }^{1}$ British Columbia Geological Survey \\ ${ }^{2}$ Lumex-marketing LLC \\ Presenting Author: alexei.rukhlov@gov.bc.ca
}

Mercury is the only metal that forms vapour haloes in soil gas and near-surface atmosphere that currently can be directly detected. Among volatile geogenic components, $\mathrm{Hg}$ vapour has been most informative in exploration, geological mapping, and earthquake prediction. This is because Hg occurs in most types of endogenic ore deposits and readily reduces to highly mobile $\mathrm{Hg}^{0}$ that emanates from mineral deposits, active faults, volcanoes, and geothermal zones. Mercury escaped into the atmosphere is diluted by turbulent diffusion and transferred with air mass movement. Hence, $\mathrm{Hg}$ vapour haloes in near-surface air occur directly above mineral deposits and faults rather than forming dispersal plumes. This contrasts with lithochemical, hydrochemical, and biochemical dispersion aureoles that can be laterally displaced or obscured by transported overburden. Low background concentrations in the atmosphere $\left(1.2\right.$ to $\left.1.5 \mathrm{ng} / \mathrm{m}^{3}\right)$ enable detecting even weak $\mathrm{Hg}$ emissions directly above sources 100 s of metres below the surface. Because of higher $\mathrm{Hg}$ vapour concentration, soil gas sampling is more commonly used than near-surface air sampling. However, soil gas sampling is not suitable across highly variable surficial materials, outcrops, felsenmeers, wet soil, bogs, water bodies, permafrost, and snow cover. This study evaluates the effectiveness of real-time $\mathrm{Hg}$ vapour measurement in air 1-50 cm above ground at 15 locations on Vancouver Island, British Columbia, Canada [1]. These sites include different types of sediment-covered and exposed mineralized zones and faults. The direct and continuous analysis using a portable RA-915M mercury analyzer reveals $\mathrm{Hg}$ vapour concentrations ranging from 0.5 to $54.4 \mathrm{ng} / \mathrm{m}^{3}$. Prominent $\mathrm{Hg}$ vapour haloes mark shear-hosted $\mathrm{Cu}-\mathrm{Ag}$-Au, epithermal $\mathrm{Au}-\mathrm{Ag}$ $\mathrm{Cu}$, and sediment-covered polymetallic volcanogenic massive sulphide mineralized zones ( 4 to $13 \mathrm{x}$ background $\mathrm{Hg}$ ). Faults are also marked by weak $\mathrm{Hg}$ vapour anomalies. Our study finds that a simple, real-time $\mathrm{Hg}$ vapour sampling of near-surface air can instantly delineate mineralized zones and faults that are buried under overburden tens of metres thick.

[1] Rukhlov, Ootes, Hickin, and Mashyanov (2021), In: Geological Fieldwork 2020, British Columbia Ministry of Energy, Mines and Low Carbon Innovation, British Columbia Geological Survey Paper 2021-01, pp. 113-143. 